\title{
Accounting
}

\section{Auditors' perceptions of their roles and responsibilities: The impact of exposure to litigation risk}

\author{
Ahmed Abdullah Saad Al-Dhubaibia ${ }^{*}$
}

${ }^{a}$ Department of Accounting, College of Business Administration, Prince Sattam Bin Abdulaziz University, Saudi Arabia

\begin{tabular}{l}
\hline C H R O N I C L E \\
\hline Article history: \\
Received: November 28, 2020 \\
Received in revised format: \\
January 302021 \\
Accepted: March 29, 2021 \\
Available online: \\
March 29, 2021 \\
\hline Keywords: \\
Auditors \\
Audit objectives \\
Responsibility \\
Liability \\
Fraud \\
Assurance \\
Litigation risk \\
Partners \\
Audit managers \\
Senior auditors \\
\hline
\end{tabular}

\section{A B S T R A C T}

The purpose of this study is to investigate the perception of auditors regarding their responsibilities and potential liabilities to third parties in the case of failure to detect fraud/material misstatements and report the findings to the appropriate party. The study proposes that auditors' perception of their own responsibilities will depend on the level of litigation threat expected by the auditor based on his or her position in the audit firm. The questionnaire was sent to the big 4 audit firms, the global audit firms other than the big 4, and to 189 different sized local audit firms registered with the Saudi Organization of Certified Public Accountants (SOCPA). The findings of this study revealed significant variations among auditors with regards to their perceptions of their own responsibilities and liabilities to financial statements' users affected by their expected level of exposure to litigation risk.

(C) 2021 by the authors; licensee Growing Science, Canada

\section{Introduction}

Despite the considerable attention given to audit practice and corporate governance following the catastrophic fraud results of large companies such as Enron, Tyco, WorldCom, and Xerox; fraud cases have been increasing worldwide with inadequate fraud detection efforts (Huang, Lin, Chiu, \& Yen, 2017; McKee, 2010). The claim of fraud investigators regarding the probability of fraud committed by General Motor Corporation's management brought the fraud concern to the attention of legislators and various stakeholders including the role and assumed responsibility of the auditors for undetected fraud. The auditing profession encounters a major risk arising from the claim of professional negligence that other parties may raise against auditors if the auditees collapse or declare bankruptcy. Failure to detect fraud or alert the stakeholders to the going concern issues early enough to take precautionary actions may result in the auditor being sued and held accountable. For instance, Noghondari and Foong (2013) reported a litigation case against the audit firm by a Malaysian public listed company. In this case, Silver Bird Group Bhd is a food industrial company that suffered a substantial loss due to financial irregularities and as a result, the company filed a legal suit against the audit firm claiming that the auditor was negligent and breached his professional responsibilities.

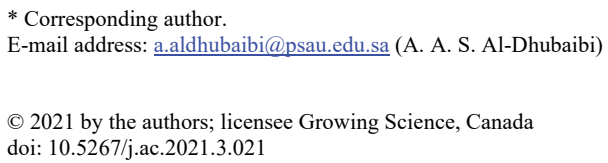


Litigation is a main concern for the audit partners as their firm ownership and personal wealth are threatened by the consequences of litigations (Lennox \& Li, 2012). Audit litigation risk drives important decisions that are made by audit firms. For instance, client acceptance or continuance decision is largely influenced by the expected litigation risk. Hogan and Martin (2009) indicated that big 4 audit firms dissociate from some of their risky clients post-Sarbanes-Oxley act in the United States after a significant increase in the litigation cases. Recent research revealed that audit quality, judgments, and outcomes are affected by individual audit partner characteristics (Robert Knechel, Vanstraelen, \& Zerni, 2015). Prior research on audit litigation risk has dealt with the causes and consequences of the litigation risk for the audit firms. Researchers have not paid attention to the impact of different levels of individual auditor exposure to litigation risk on the perception of auditors or their responses to the estimated level of risk.

This study uses the position of auditors as a proxy to reflect the level of individual auditor exposure to audit litigation risk. For this purpose, the audit partner is identified as the highest position and the most expected individual to be affected by the consequences of litigation. In contrast, the lower position in the audit firm which is the junior auditor is identified as the least expected individual to be affected by the litigation consequences.

\section{Literature Review}

Corporate financial fraud has caused high profile corporations to collapse and shareholders to lose billions of dollars resulting in less confidence of investors in the financial markets and creating serious problems for shareholders, governments, and other affected parties (Peterson \& Buckhoff, 2004; Rezaee, Larry Crumbley, \& Elmore, 2004). Fraud incidents are increasing despite the variety of methods and strategies that companies use to combat and detect fraud. E.g Bierstaker, Brody, and Pacini (2006) Surveyed 34 methods which accountants confirmed to use in order to prevent and detect fraud. Nevertheless, fraud continued to occur. The 2009 report of the Computer Security Institute in the United State revealed a significant increase in the financial fraud cases in its 14th annual survey (Reddy, Venter, \& Olivier, 2012). Recently, the Association of Certified Fraud Examiners ((ACFE), 2018) has issued the Report to The Nation's 2018 Global Study on Occupational Fraud and Abuse and declared a total loss of USD 7.1 billion caused by the 2,690 cases of fraud surveyed during the year 2017 in 125 countries worldwide. The report emphasized that this amount of loss is not a representative figure to the total global fraud loss. The report stated that the real global fraud cost is estimated to be much higher considering the indirect cost of negative impact of fraud on businesses.

Tang and Karim (2019) pointed out that despite the detailed explanations provided by auditing standards on the auditors' tasks of understanding fraud, assessing risk, exerting professional skepticism, responding properly to the assessed level of risk, documenting and communicating findings with management; yet, these guidelines might be interpreted and implemented differently by auditors. Louwers, Henry, Reed, and Gordon (2008) Investigated a considerable number of audit failures to detect fraud by examining 43 SEC enforcement actions against auditors in the United States for deficiencies in auditing of relatedparty transactions. Their findings revealed that the failure was due to the lack of due professional care and less professional skepticism of auditors rather than the insufficiency of auditing standards. Furthermore, fraud detection procedures performed by auditors are found to be associated with other factors such as their perceived responsibility for fraud detection (DeZoort \& Harrison, 2018), audit experience (Payne \& Ramsay, 2005), cultural differences from country to another (Bik \& Hooghiemstra, 2018) and audit judgment (Tang \& Karim, 2019).

Auditing standards recently attempted to make the work of auditors more transparent by providing more details of the auditor's work and findings in the audit report to improve the communications between auditors, auditees, and financial statements' users. However, financial statements' users still have unreasonable expectations of the auditors' responsibilities especially for detecting and reporting fraud (Fulop, Tiron-Tudor, \& Cordos, 2019). Professional auditors have attributed the increased litigations against auditors to those unreasonable expectations and believed that they are the main source of public criticism of the auditing profession (Al-Dhubaibi, 2020; Lee, Ali, \& Bien, 2009).

Perceived audit litigation risk by partners and managers increases the audit fees as the auditors may increase the insurance against future litigation losses (Venkataraman, Weber, \& Willenborg, 2008). However, the risk of an audit partner's litigation by any number of parties provides significant motivation for the audit partners to preserve high-quality audit (Honigsberg, 2019).

The Public Company Accounting Oversight Board (PCAOP) in the United States requested (in the 2009 concept release) the audit engagement's partner only to sign the audit report considering "the engagement's partner is solely responsible for the audit engagement and its performance". Later in 2011, the PCAOP proposed an amendment that requires the engagement partner's name to be disclosed in the audit report instead of the signature requirement. This change was proposed due to the partner's high legal liability assumed in the signature requirement (Board, 2009, 2011). These requirements raised the concerns of the audit firms' partners regarding the implied litigation exposure or the probable reputational effect for the individual partner (Cole, 2014). 
Researchers have used several methods to measure the audit firm expected litigation risk. Kang, Lee, Mande, and Woo (2019) used, among others, the proportion of partners to total auditors in the audit firms as a proxy to measure the litigation risk. They have argued that a higher number of audit partners in an audit firm could lower the exposure to litigation risk as they use their experience in supervising, monitoring, and reviewing the work of auditors in addition to their responsibilities of making the final decision about the type of audit opinion. However, their aim was to measure the exposure of the audit firm, not the individual auditor, to the litigation risk.

\section{Research Methodology}

Studies that explore attitudes, opinions, and perceptions of individuals have promoted the use of surveys as the most appropriate tool for data collection of this type (Smith, Omar, Iskandar, \& Baharuddin, 2005). Research in the area of auditing has used the mail survey method widely as it promotes frankness, objectivity, and keeps the confidentiality of the respondents (Smith et al., 2005). Recently, researchers started to use online surveys utilizing many online softwares to structure and disseminate the questionnaires to targeted respondents. For example, Gonthier-Besacier, Hottegindre, and Fine-Falcy (2016) utilized the SurveyMonkey software in their study about the audit quality to build up the questionnaire and send it to auditors in France. An online survey has been used in this study for data collection purposes. The closed-question design is used in order to facilitate the answers and save the time of the respondents. The clarity of the questions is maintained to increase the expected number of responses and secure more relevant and objective answers from the respondents. Each question consists of a differential belief statement intended to explore the perception of auditors' groups namely; partners, audit managers, senior auditors, and auditors. These statements have been adopted from previous studies conducted on auditors' responsibilities such as Alleyne and Howard (2005), Bierstaker et al. (2006), Best, Buckby, and Tan (2001), Kassem (2018), Lin and Chen (2004), Noghondari and Foong (2013), and Ruhnke and Schmidt (2014).

The four groups of auditors were categorized based on their roles and positions in their respective audit firms as a proxy for the different levels of exposure to litigation risk. Partners have the ultimate responsibility for the audit work. Partners are responsible for the acceptance or continuance of the clients, planning the audit, reviewing the auditors' work, and finally signing the audit reports. Legislations hold the signing partner primarily responsible for the reasonableness of audit results and then the rest of the audit firm's partners. Accordingly, audit partners are more exposed to litigation risk if they fail to exert due care in supervising the audit work, preserving the required level of audit quality control, and comply with auditing standards and other related regulations. The other three groups (audit managers, senior auditors, and auditors) are less exposed to litigation risk. However, the higher the position of the auditors of these groups, the higher the responsibility for the audit work and results; and consequently the higher the exposure to litigation risk.

A Seven-Point Likert Scale has been used to measure each statement where " $1=$ strongly disagree; 7 = strongly agree". Each number in the scale reflects the level of agreement or disagreement of the respondent. The questionnaire was sent to all audit firms registered with the professional body of Saudi Arabia (the Saudi Organization for Certified Public Accountants - SOCPA). Emails of audit firms and offices were obtained from the website of SOCPA. In addition to the big 4 audit firms and the global firms other than the big 4, the questionnaire was sent to 189 different sized local audit firms and offices. The email recipient was requested to forward the email to the audit firm's partners, managers, and other auditors. To secure an adequate number of responses from each group, the personal emails of partners and managers have been taken out from the audit firms' websites and then the questionnaire was sent to each individual partner and manager. In addition, the researcher has visited a number of audit firms personally and submitted the questionnaire to the auditors by hand. Following up has been made through phone calls to remind respondents and ensure the understandability of the questions. Out of the 280 questionnaires distributed by emails and by hands, 88 responses have been received with a response rate of $31 \%$. Analysis of data has been performed using the OneWay between-groups Analysis of Variance (ANOVA) to observe any significant differences between partners, audit managers, senior auditors, and auditors.

\section{Results and Discussion}

\subsection{Demographics of respondents}

Out of 280 questionnaires that were sent to auditors, 88 valid responses have been received with a response rate of $31 \%$. Table 1 and Fig. 1 presents the respondents' profile of auditors. Information about auditors includes the respondent's position, years of experience, qualification, audit firm he or she is working for, and other demographic information. Out of the 88 responded auditors, $36(41 \%)$ are working for global audit firms while the rest, $52(59 \%)$ are working for local audit firms/offices. Half of the auditors who are working for global audit firms, 18 (20.5\%) came from the big 4 audit firms while the other half, 18 (20.5\%) are working for global audit firms other than the big 4 . The rest of auditors are working for different sized local audit firms as follows; 14 (15.9\%) working for large local audit firms, 26 (29.5\%) working for medium-size local audit firms/offices, and 12 $(13.6 \%)$ working for small local audit firms/offices. Auditors who responded to the questionnaire occupy various levels of responsibilities in their respective firms ranging from partners (the highest position in the audit firms) to auditors (the starting position). In this regard, 20 partners comprising $22.7 \%$ have responded to the questionnaire which considered a creditable result 
for this type of survey as the audit partners are normally busy most of the time and it is mostly hard to get them to respond to a questionnaire. The remainder of auditors were audit managers 18 (20.5\%), senior auditors 14 (15.9\%), and auditors 36 (40.9\%). Information from table 1 shows that more than half of the auditors $49(55.7 \%)$ are having experience more than four years in the audit profession. Auditors with experience from 2 to 4 years were $19(21.6 \%)$ while auditors with less than two years of experience were 20 (22.7\%). Auditors' qualifications varied with a minimum of a bachelor's degree in accounting. Two auditors hold a Ph.D. degree, 13 (14.8\%) hold a master's degree, 11 (12.5\%) hold a professional certification in accounting, while the majority of auditors 62 (70.5\%) hold a bachelor degree in accounting. Practicing auditors in Saudi Arabia must be licensed by the Saudi Organization for Certified Public Accountants (SOCPA) which requires, among others, passing certain professional exams. However, this is a requirement for founders and partners of audit firms/offices only. Other positions such as audit managers, senior auditors and auditors may work for those audit firms/offices and they could have passed SOCPA exam and registered as SOCPA members or they could have merely an academic or other professional certificates in accounting (i.e. CPA, ACCA, ACA ...etc.) and thus, are not SOCPA members. Of those who have responded to the survey, 49 (55.7\%) are SOCPA members while the rest, $39(44.3 \%)$ are not SOCPA members. The diversity of auditors' positions, qualifications, experience, type, and size of their audit firms indicate that the respondents are a good representative sample of the overall population that consists of practicing auditors in Saudi Arabia. Moreover, the level of experience and qualifications of respondents indicate that the respondents are informed about the responsibilities of auditors and other concepts introduced in the questionnaire statements.

Table 1

Profile of the Respondents

\begin{tabular}{llrr}
\hline & & $n$ & Percentage \\
\hline Type of Audit Firm/Office & One of the Big 4 Audit Firms & 18 & $20.5 \%$ \\
& Audit Firm with Foreign Membership (other than big 4) & $20.5 \%$ \\
& Large Local Audit Firmloffice & 18 & 14 \\
& Medium Local Audit Firmloffice & 26 & $15.9 \%$ \\
& Small Local Audit Firmloffice & $29.5 \%$ & 12 \\
\hline & Total & $\mathbf{8 8}$ & $\mathbf{1 0 0 . \%}$ \\
\hline
\end{tabular}

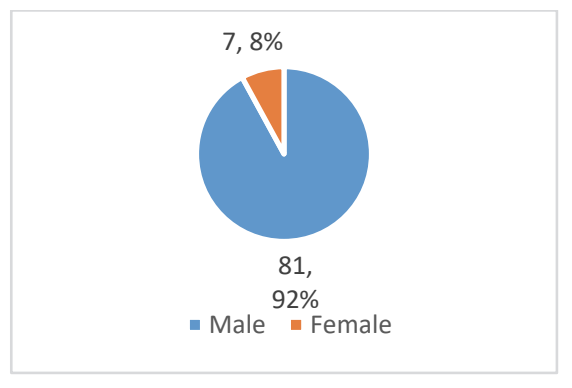

Gender

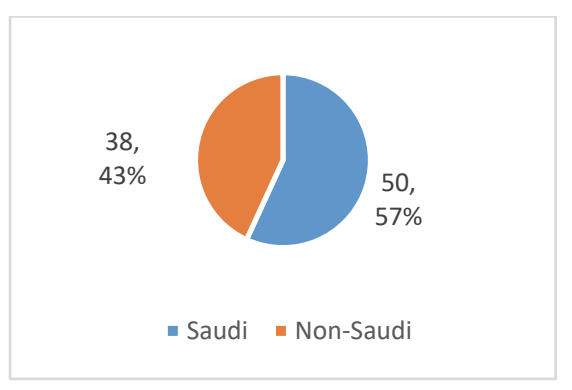

Nationality

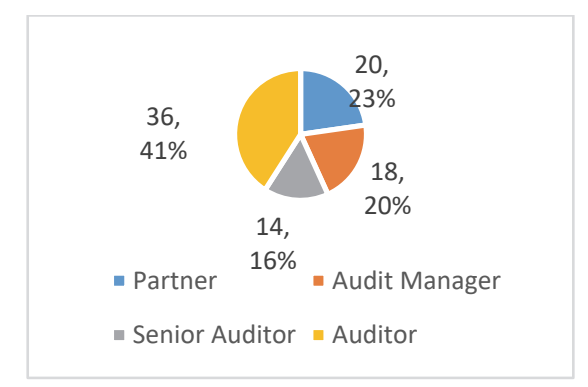

Position

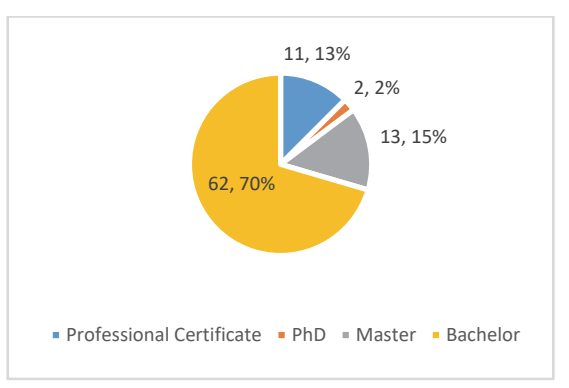

Qualification

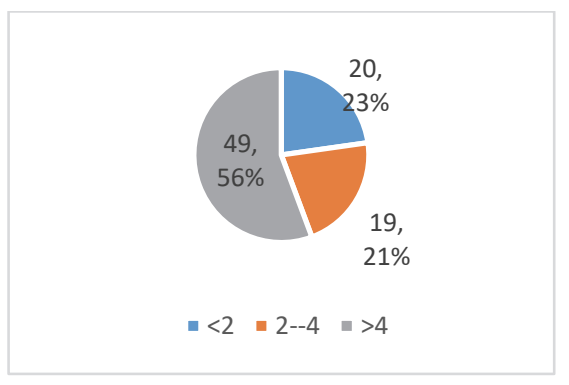

Years of Experience in Auditing

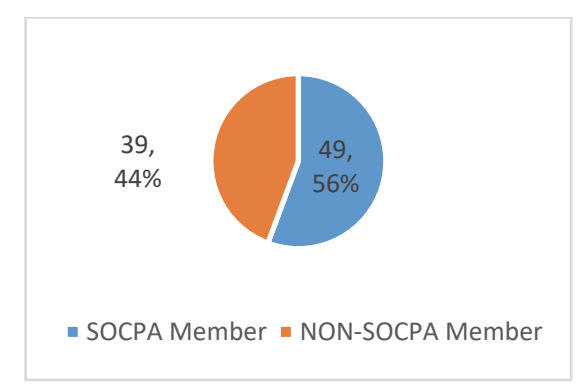

SOCPA Membership

Fig. 1. Personal characteristics of the participants

\subsection{Results from the differential belief statements}

Results presented in Tables 2 and 3 illustrate the perception of auditors regarding their own responsibilities. The two tables demonstrate the significant variation between four groups of auditors that were categorized based on their roles and positions in their respective audit firms as a proxy for the different levels of exposure to litigation risk. The perceptions of each auditors' group were obtained from their responses to 15 differential statements about audit importance and overall audit objectives, the 
general responsibilities of the independent external auditor, auditor's responsibilities for fraud detection, the liability of auditors to third parties in the case of litigation, and expected level of assurance in which auditors provide in the audit report. Table 2 presents the mean score of responses of each group of respondents for each statement and the significance level of variation between groups provided by ANOVA. For more informative analysis, Table 3 provides the mean differences and level of significance between each group and another which were obtained from Tukey Post Hoc Analysis.

\subsubsection{The role and objective of an audit}

Responses to the statements 1-3 related to the objective, importance, and role of the audit showed no variation in auditors' perceptions as the differences between mean scores were not significant. Partners, audit managers, senior auditors, and auditors agree that audit increases the reliability of financial information. In addition, auditors believe that an audit increases the credibility of financial statements to be used by managers for planning and decision making. Furthermore, the overall objective of the auditors is agreed upon by the four groups. Auditors understand that the primary objective of an audit is to provide an opinion on the fair presentation of the financial statements.

\subsubsection{General responsibilities of the independent external auditor:}

Statements 4-7 in tables 2 and 3 stipulate some of what could be assumed by financial statements' users to fall under the responsibilities of external auditors. Responses of auditors to these statements as displayed in Tables 2 and 3 do confirm that some auditors agree on the proposition that the auditors should take the responsibilities stated in these statements while other auditors do not agree that these duties fall under their responsibilities. Statement 4 states that auditors should guarantee that audited financial statements are accurate. This statement emphasizes that once financial statements are audited and the audit report is issued, auditor guarantee to financial statements' users that the information included in the financial statements are accurate and error-free.

The responses of auditors to this statement varies significantly. Results in Table 2 showed a significant difference between auditors' groups' mean score at $(P<0.01)$. When looking at the responses mean scores of partners $(3.7)$, audit managers $(4.72)$, senior auditors (5.64), and auditors (5.56), it is clear that the higher the position of the respondent, the less the agreement about the statement. With the least mean score of all groups (3.7), partners disagree that they should guarantee the accuracy of the audited financial statements. Partners understand that the accuracy of the information included in the financial statements is the responsibility of management. Post Hoc analysis for this statement displayed in table 3 showed that there are significant differences between partners and both senior auditors and auditors. When examining the effect of experience as a possible cause for this variation, the results revealed no differences in the mean scores of auditors' groups categorized based on the number of years of experience. Therefore, the level of exposure to litigation risk is the only explanatory factor for the variation between audit partners and; senior auditors and auditors with regards to the perception of each group about the responsibility of financial statements accuracy.

In their responses to statement 5, auditors almost agree that they don't have to prepare the financial statements of their clients. This is indicated by the mean score of the four groups' responses which are all below the average of the scale (1-7). Auditing standards state it clearly that the preparation of financial statements is the sole responsibility of the company's management. Moreover, auditors clarify the responsibility of their clients' management for the financial statements' preparation before they start the audit through the engagement letter (contract) and at the end of the audit within the audit report. It is surprising that some auditors believe that they should prepare the clients' financial statements. The perception of junior auditors regarding this issue could be attributed to the practice where most of the audit firms and offices assist their clients in the proper preparation and classification of financial statements. Due to this common and continuous practice, some junior auditors may understand that auditors should prepare the client's financial statements. However, partners showed strong disagreement with this statement with a response mean score of (1.9) and a significant difference with auditors $(3.28)$ at $(P<0.10)$ level.

Statement 6 implies that one of the auditors' responsibilities is to confirm the compliance of audited financial statements with tax law. Results of the responses to this statement which is presented in Table 2 revealed a significant difference between groups at $(P<0.01)$ level. Detailed results presented in table 3 showed that the significant difference noticed in ANOVA results (between groups) have been found to be between partners and each of the other three groups namely: audit managers at $(P<$ $0.05)$, senior auditors at $(P<0.01)$, and auditors at $(P<0.01)$ levels. In the meanwhile, there are no significant differences between any of the three groups (other than partners) and another. The responses mean scores of audit managers (5.61), senior auditors (6.29), and auditors (5.86) suggest that these three groups do believe that it is auditors' responsibility to ensure the compliance of the financial statements with tax law. However, partners have less agreement about this point with a mean score of (4.1) that is significantly different from the mean score of each of the other three groups. The refrainment of partners from this type of responsibility is due to the fact that they are the ultimate group that could be exposed to the litigation risk if they fail to carry out their responsibilities properly. 


\begin{tabular}{|c|c|c|c|c|c|c|c|}
\hline & \multirow[b]{2}{*}{ Statement } & \multicolumn{4}{|c|}{ Mean Score } & \multicolumn{2}{|c|}{$\begin{array}{c}\text { ANOVA } \\
\text { (Between Groups) }\end{array}$} \\
\hline & & $\begin{array}{l}\text { Partner } \\
(n=20)\end{array}$ & $\begin{array}{l}\text { Audit } \\
\text { Manager } \\
(n=18)\end{array}$ & $\begin{array}{l}\text { Senior } \\
\text { Auditor } \\
(n=14)\end{array}$ & $\begin{array}{l}\text { Auditor } \\
(n=36)\end{array}$ & $F$-value & $p$-value \\
\hline 1 & $\begin{array}{l}\text { All business entities must be audited by CPAs (independent external } \\
\text { auditors) to ensure truthfulness and reliability of accounting } \\
\text { information }\end{array}$ & 6.15 & 6.39 & 6.21 & 6.5 & .414 & .743 \\
\hline 2 & $\begin{array}{l}\text { Audited financial statements provide more reliable and objective } \\
\text { information for decision making compared to unaudited financial } \\
\text { statements }\end{array}$ & 6.75 & 6.44 & 6.86 & 6.5 & 1.417 & .244 \\
\hline 3 & $\begin{array}{l}\text { The overall objective of the auditor is to express an opinion on } \\
\text { whether the financial statements are presented fairly, in all material } \\
\text { respect. }\end{array}$ & 6.95 & 6.22 & 6.5 & 6.61 & 2.119 & .104 \\
\hline 4 & $\begin{array}{l}\text { Auditors should guarantee that the audited financial statements are } \\
\text { accurate. }\end{array}$ & 3.7 & 4.72 & 5.64 & 5.56 & $4.364 * * *$ & .007 \\
\hline 5 & Auditors should prepare the auditee's financial statements. & 1.9 & 2.56 & 2.21 & 3.28 & $2.275^{*}$ & .086 \\
\hline 6 & $\begin{array}{l}\text { Auditors should ensure that audited financial statements comply with } \\
\text { the tax law. }\end{array}$ & 4.1 & 5.61 & 6.29 & 5.86 & $6.671 * * *$ & .000 \\
\hline 7 & $\begin{array}{l}\text { Auditors should guarantee that the audited financial statements are } \\
\text { free of intentional or unintentional material misstatements. }\end{array}$ & 2.75 & 4.33 & 4.86 & 5.56 & $6.725 * * *$ & .000 \\
\hline 8 & $\begin{array}{l}\text { It is the responsibility of the auditor to uncover fraud and report to } \\
\text { appropriate authorities. }\end{array}$ & 2.3 & 3.17 & 3.57 & 3.94 & $2.935 * *$ & .038 \\
\hline 9 & $\begin{array}{l}\text { Auditing Standards should make auditors responsible for detecting } \\
\text { and reporting fraud. }\end{array}$ & 2.15 & 3 & 3.5 & 4.28 & $4.779 * * *$ & .004 \\
\hline 10 & $\begin{array}{l}\text { The auditor's responsibility in relation to fraud should be clearly } \\
\text { indicated in the audit report. }\end{array}$ & 3.15 & 3.78 & 4.86 & 4.92 & $2.865 * *$ & .041 \\
\hline 11 & $\begin{array}{l}\text { The auditor is primarily responsible for the truthfulness and } \\
\text { reliability of financial statements. }\end{array}$ & 2.7 & 3.78 & 4 & 3.92 & 1.698 & .174 \\
\hline 12 & $\begin{array}{l}\text { Auditing Standards should make auditors legally liable for } \\
\text { subsequent discovery of misstated financial statements. }\end{array}$ & 2 & 2.78 & 4 & 4.31 & $6.298 * * *$ & .001 \\
\hline 13 & An auditor is responsible if the company goes bankrupt due to fraud. & 1.65 & 2.72 & 3.43 & 3.36 & $3.953 * *$ & .011 \\
\hline 14 & $\begin{array}{l}\text { Auditors are liable for losses of interested parties if failed to disclose } \\
\text { potential fraud in the audit report. }\end{array}$ & 1.75 & 2.56 & 2.36 & 3.03 & $2.350 *$ & .078 \\
\hline 15 & $\begin{array}{l}\text { Financial statements' users can have absolute assurance }(100 \%) \text { that } \\
\text { the audited financial statements contain no material misstatements } \\
\text { due to fraud or errors. }\end{array}$ & 1.8 & 3.33 & 3.64 & 3.89 & $4.540 * * *$ & .005 \\
\hline
\end{tabular}

The significance levels are indicated as: *significant at the 0.10 level; **significant at the 0.05 level; and ***significant at the 0.01 level.

Statement 7 assumes that auditors should guarantee audited financial statements are free of intentional or unintentional material misstatements. The results illustrated in Table 2 revealed a strong agreement with this assumption by all auditors' groups except the partners' group. Audit managers with a mean score of (4.33), senior auditors (4.86), and auditors (5.56) largely assume that financial statements users obtain a guarantee from auditors that audited financial statements are free completely from any intentional or unintentional material misstatements. This assumption is not in accordance with the instructions and guidelines of the International Standards on Auditing (ISA). Furthermore, auditors state their responsibilities towards uncovering financial statements' material misstatements in the audit contract (an engagement letter) and in the audit report according to the requirements of ISA. In the audit report, the auditor may state that due to the limitations of the test bases of audit work, a material misstatement, whether due to error or fraud, may remain undetected. Since the audit report is signed by the audit partner, the partners seem to understand this point. The mean score of the partners' response to this statement (2.75) indicates that they assume no guarantee to the financial statements' users that the audited financial statements are free of intentional or unintentional material misstatements. The results in Table 2 for this statement showed a significant difference between groups at $(P<0.01)$ level. This difference is explained in Table 3 as a difference between partners and senior auditors at $(P<0.05)$ and between partners and auditors at $(P<0.01)$ levels. This result is a clear indicator of the effect of the level of exposure to litigation risk on auditor perception about their responsibilities. Junior auditors who expect no litigation risk may increase the expectations about their roles and responsibilities. In contrast, partners who face the highest level of litigation risk minimize the expectations about their responsibilities to minimize the litigation risk that may result from failing to fulfill those responsibilities.

\subsubsection{Auditors' responsibilities for fraud detection:}

Statements 8-10 in Tables 2 and 3 provide propositions related to the responsibility of the auditors for fraud detection and prevention. This part of the study and the next part (auditors' liability) is the obvious evidence for the effect of exposure to litigation risk on the auditors' perception. At most, auditors are exposed to litigation risk if they fail to detect fraud and draw the attention of stakeholders early enough to take protective action. Most litigation cases against auditors followed the 
A. A. S. Al-Dhubaibi et al. /Accounting 7 (2021)

bankruptcy of companies or those cases in which fraud was discovered after auditors had issued their reports whereas failed to detect fraud or inform about it. Results presented in Table 2 revealed a significant variation (between groups) in the mean scores of each of the three statements related to the responsibilities of auditors for detecting and reporting fraud. Statement 8 states that it is the responsibility of the auditor to uncover fraud and report to appropriate authorities. Responses of auditors to this statement showed disagreement of partners with a mean score of (2.3), audit managers (3.17), and senior auditors (3.57). Junior auditors showed some sort of agreement with a mean score of (3.94). The significant difference was noticed

Table 3

Post Hoc Tests (Multiple Comparisons)

\begin{tabular}{|c|c|c|c|c|c|c|}
\hline & Statement & $\begin{array}{l}\text { (I) Position of the } \\
\text { Respondent }\end{array}$ & $\begin{array}{l}\text { (J) Position of the } \\
\text { Respondent }\end{array}$ & $\begin{array}{c}\text { Mean Difference (I- } \\
J)\end{array}$ & $\begin{array}{l}\text { Std. } \\
\text { Error }\end{array}$ & Sig. \\
\hline \multirow[t]{6}{*}{1} & \multirow{6}{*}{$\begin{array}{l}\text { All business entities must be audited by CPAs } \\
\text { (independent external auditors) to ensure truthfulness and } \\
\text { reliability of accounting information }\end{array}$} & \multirow[t]{3}{*}{ Partner } & Audit Manager & -.239 & .401 & .933 \\
\hline & & & Senior Auditor & -.064 & .430 & .999 \\
\hline & & & Auditor & -.350 & .345 & .741 \\
\hline & & \multirow[t]{2}{*}{ Audit Manager } & Senior Auditor & .175 & .440 & .979 \\
\hline & & & Auditor & -.111 & .357 & .989 \\
\hline & & Senior Auditor & Auditor & -.286 & .389 & .883 \\
\hline \multirow[t]{6}{*}{2} & \multirow{6}{*}{$\begin{array}{l}\text { Audited financial statements provide more reliable and } \\
\text { objective information for decision making compared to } \\
\text { unaudited financial statements }\end{array}$} & \multirow[t]{3}{*}{ Partner } & Audit Manager & .306 & .232 & .556 \\
\hline & & & Senior Auditor & -.107 & .249 & .973 \\
\hline & & & Auditor & .250 & .199 & .594 \\
\hline & & \multirow[t]{2}{*}{ Audit Manager } & Senior Auditor & -.413 & .255 & .373 \\
\hline & & & Auditor & -.056 & .206 & .993 \\
\hline & & Senior Auditor & Auditor & .357 & .225 & .392 \\
\hline \multirow[t]{6}{*}{3} & \multirow{6}{*}{$\begin{array}{l}\text { The overall objective of the auditor is to express an opinion } \\
\text { on whether the financial statements are presented fairly, in } \\
\text { all material respect }\end{array}$} & \multirow[t]{3}{*}{ Partner } & Audit Manager & $.728^{*}$ & .293 & .069 \\
\hline & & & Senior Auditor & .450 & .314 & .482 \\
\hline & & & Auditor & .339 & .251 & .534 \\
\hline & & \multirow[t]{2}{*}{ Audit Manager } & Senior Auditor & -.278 & .321 & .823 \\
\hline & & & Auditor & -.389 & .260 & .444 \\
\hline & & Senior Auditor & Auditor & -.111 & .284 & .979 \\
\hline \multirow[t]{6}{*}{4} & \multirow{6}{*}{$\begin{array}{l}\text { Auditors should guarantee that the audited financial } \\
\text { statements are accurate. }\end{array}$} & \multirow[t]{3}{*}{ Partner } & Audit Manager & -1.022 & .648 & .397 \\
\hline & & & Senior Auditor & $-1.943 * *$ & .695 & .032 \\
\hline & & & Auditor & $-1.856^{* * *}$ & .556 & .007 \\
\hline & & Audit Manager & Senior Auditor & -.921 & .710 & .568 \\
\hline & & & Auditor & -.833 & .576 & .473 \\
\hline & & Senior Auditor & Auditor & .087 & .628 & .999 \\
\hline 5 & Auditors should prepare the auditee's financial statements. & Partner & Audit Manager & -.656 & .661 & .755 \\
\hline & & & Senior Auditor & -.314 & .709 & .971 \\
\hline & & & Auditor & $-1.378^{*}$ & .568 & .080 \\
\hline & & Audit Manager & Senior Auditor & .341 & .725 & .965 \\
\hline & & & Auditor & -.722 & .587 & .610 \\
\hline & & Senior Auditor & Auditor & -1.063 & .641 & .352 \\
\hline 6 & Auditors should ensure that audited financial statements & Partner & Audit Manager & $-1.511 * *$ & .527 & .026 \\
\hline & comply with the tax law. & & Senior Auditor & $-2.186 * * *$ & .566 & .001 \\
\hline & & & Auditor & $-1.761 * * *$ & .453 & .001 \\
\hline & & Audit Manager & Senior Auditor & -.675 & .578 & .650 \\
\hline & & & Auditor & -.250 & .468 & .951 \\
\hline & & Senior Auditor & Auditor & .425 & .511 & .840 \\
\hline 7 & Auditors should guarantee that the audited financial & Partner & Audit Manager & -1.583 & .735 & .145 \\
\hline & statements are free of intentional or unintentional material & & Senior Auditor & $-2.107 * *$ & .789 & .044 \\
\hline & misstatements. & & Auditor & $-2.806^{* * *}$ & .631 & .000 \\
\hline & & Audit Manager & Senior Auditor & -.524 & .807 & .915 \\
\hline & & & Auditor & -1.222 & .653 & .249 \\
\hline & & Senior Auditor & Auditor & -.698 & .713 & .761 \\
\hline 8 & It is the responsibility of the auditor to uncover fraud and & Partner & Audit Manager & -.867 & .657 & .554 \\
\hline & report to appropriate authorities. & & Senior Auditor & -1.271 & .705 & .279 \\
\hline & & & Auditor & $-1.644 * *$ & .564 & .023 \\
\hline & & Audit Manager & Senior Auditor & -.405 & .721 & .943 \\
\hline & & & Auditor & -.778 & .584 & .546 \\
\hline & & Senior Auditor & Auditor & -.373 & .637 & .936 \\
\hline 9 & Auditing Standards should make auditors responsible for & Partner & Audit Manager & -.850 & .676 & .592 \\
\hline & detecting and reporting fraud. & & Senior Auditor & -1.350 & .725 & .252 \\
\hline & & & Auditor & $-2.128 * * *$ & .580 & .002 \\
\hline & & Audit Manager & Senior Auditor & -.500 & .741 & .906 \\
\hline & & & Auditor & -1.278 & .600 & .153 \\
\hline & & Senior Auditor & Auditor & -.778 & .655 & .636 \\
\hline 10 & The auditor's responsibility in relation to fraud should be & Partner & Audit Manager & -.628 & .778 & .851 \\
\hline & clearly indicated in the audit report. & & Senior Auditor & -1.707 & .835 & .180 \\
\hline & & & Auditor & $-1.767 * *$ & .668 & .047 \\
\hline & & Audit Manager & Senior Auditor & -1.079 & .854 & .588 \\
\hline & & & Auditor & -1.139 & .692 & .358 \\
\hline & & Senior Auditor & Auditor & -.060 & .755 & 1.000 \\
\hline
\end{tabular}


Table 3

Post Hoc Tests (Multiple Comparisons) (Continued)

\begin{tabular}{|c|c|c|c|c|c|c|}
\hline & Statement & $\begin{array}{l}\text { (I) Position of the } \\
\text { Respondent }\end{array}$ & $\begin{array}{l}(J) \text { Position of the } \\
\text { Respondent }\end{array}$ & $\begin{array}{l}\text { Mean Difference } \\
(\mathrm{I}-\mathrm{J})\end{array}$ & $\begin{array}{l}\text { Std. } \\
\text { Error }\end{array}$ & Sig. \\
\hline \multirow[t]{6}{*}{11} & \multirow{6}{*}{$\begin{array}{l}\text { The auditor is primarily responsible for the truthfulness } \\
\text { and reliability of financial statements. }\end{array}$} & \multirow[t]{3}{*}{ Partner } & Audit Manager & -1.078 & .684 & .398 \\
\hline & & & Senior Auditor & -1.300 & .733 & .294 \\
\hline & & & Auditor & -1.217 & .587 & .170 \\
\hline & & \multirow[t]{2}{*}{ Audit Manager } & Senior Auditor & -.222 & .750 & .991 \\
\hline & & & Auditor & -.139 & .608 & .996 \\
\hline & & Senior Auditor & Auditor & .083 & .663 & .999 \\
\hline \multirow[t]{6}{*}{12} & \multirow{6}{*}{$\begin{array}{l}\text { Auditing Standards should make auditors legally liable for } \\
\text { subsequent discovery of misstated financial statements. }\end{array}$} & \multirow[t]{3}{*}{ Partner } & Audit Manager & -.778 & .671 & .655 \\
\hline & & & Senior Auditor & $-2.000 * *$ & .720 & .034 \\
\hline & & & Auditor & $-2.306^{* * *}$ & .576 & .001 \\
\hline & & \multirow[t]{2}{*}{ Audit Manager } & Senior Auditor & -1.222 & .736 & .351 \\
\hline & & & Auditor & $-1.528^{*}$ & .597 & .058 \\
\hline & & Senior Auditor & Auditor & -.306 & .651 & .966 \\
\hline \multirow[t]{6}{*}{13} & \multirow{6}{*}{$\begin{array}{l}\text { An auditor is responsible if the company goes bankrupt } \\
\text { due to fraud. }\end{array}$} & \multirow[t]{3}{*}{ Partner } & Audit Manager & -1.072 & .620 & .315 \\
\hline & & & Senior Auditor & $-1.779 * *$ & .665 & .044 \\
\hline & & & Auditor & $-1.711 * *$ & .532 & .010 \\
\hline & & \multirow[t]{2}{*}{ Audit Manager } & Senior Auditor & -.706 & .680 & .727 \\
\hline & & & Auditor & -.639 & .551 & .654 \\
\hline & & Senior Auditor & Auditor & .067 & .601 & .999 \\
\hline \multirow[t]{6}{*}{14} & \multirow{6}{*}{$\begin{array}{l}\text { Auditors are liable for losses of interested parties if failed } \\
\text { to disclose potential fraud in the audit report. }\end{array}$} & \multirow[t]{3}{*}{ Partner } & Audit Manager & -.806 & .568 & .491 \\
\hline & & & Senior Auditor & -.607 & .609 & .751 \\
\hline & & & Auditor & $-1.278 * *$ & .487 & .050 \\
\hline & & \multirow[t]{2}{*}{ Audit Manager } & Senior Auditor & .198 & .623 & .989 \\
\hline & & & Auditor & -.472 & .504 & .785 \\
\hline & & Senior Auditor & Auditor & -.671 & .550 & .617 \\
\hline \multirow[t]{6}{*}{15} & \multirow{6}{*}{$\begin{array}{l}\text { Financial statements' users can have absolute assurance } \\
(100 \%) \text { that the audited financial statements contain no } \\
\text { material misstatements due to fraud or errors. }\end{array}$} & \multirow[t]{3}{*}{ Partner } & Audit Manager & -1.533 & .676 & .114 \\
\hline & & & Senior Auditor & $-1.843^{*}$ & .725 & .061 \\
\hline & & & Auditor & $-2.089 * * *$ & .581 & .003 \\
\hline & & \multirow[t]{2}{*}{ Audit Manager } & Senior Auditor & -.310 & .742 & .975 \\
\hline & & & Auditor & -.556 & .601 & .792 \\
\hline & & Senior Auditor & Auditor & -.246 & .656 & .982 \\
\hline
\end{tabular}

The significance levels are indicated as: *significant at the 0.10 level; **significant at the 0.05 level; and ***significant at the 0.01 level.

(as illustrated in Table 3 ) only between partners and auditors at $(P<0.05)$. When statement 9 suggested that auditing standards should make auditors responsible for detecting and reporting frauds, the responses of the auditors ranged from strong disagreement by partners with a mean score of (2.15), disagreement by audit managers (3), and senior auditors (3.5) to an agreement by auditors (4.28). Post Hoc analysis in table 3 showed a significant difference between partners and auditors at $(P$ $<0.01)$ level. Statement 10 proposes that the auditor's responsibility in relation to fraud should be clearly indicated in the audit report. Responses to this proposition showed a disagreement by partners with a mean score of (3.15) and an agreement by audit managers (3.78), senior auditors (4.86), and auditors (4.92) with a significant difference between partners and auditors at $(P<$ $0.05)$ level.

\subsubsection{Liability of auditors to third parties:}

Statements 12-14 put forward the suggestion that auditors must be held liable and must compensate financial statements' users for any losses or consequences of unreported misstatements in the audited financial statements. Moreover, these statements suggest that auditors should be held responsible if the auditee went bankrupt or suffered considerable losses due to fraud, irrespective of the amount and quality of audit work if failed to raise the going concern matter or modify the report for the undetected fraud. These statements are looking ahead to the liability that third parties might request the auditors to pay off in case that the litigation is raised against the auditors.

Statement 12 suggests that if a misstatement is subsequently discovered, the auditor must be liable to affected parties by its amount of incurred losses. Responses to this statement as presented in table 2 showed a significant difference between groups at $(P<0.01)$ level. Partners and audit managers disagree on the auditor's responsibility for subsequently discovered misstatement in the financial statements with a response mean score of (2) and (2.78) respectively. However, senior auditors and auditors showed an agreement with the statement with a mean score of (4) and (4.31) respectively. Detailed results of the Post Hoc analysis presented in table 3 indicated a significant difference between partners and senior auditors at $(P<0.01)$, partners and auditors at $(P<0.01)$, and audit managers and auditors at $(P<0.10)$ levels.

The second statement in this part (statement No. 13) proposes that the auditor should be made liable to shareholders of the auditee if the company announced bankruptcy due to committed fraud in which the auditor failed to detect or report to the appropriate parties. The four groups of the auditors showed disagreement with the statement with a mean score from partners (1.65), audit managers (2.72), senior auditors (3.43), and auditors (3.36). despite the disagreement of the four groups with this proposition, results of the Post Hoc Analysis revealed significant differences in the level of the disagreement between partners 
and both, senior auditors and auditors at $(P<0.05)$ level. Partners refuse this proposition strongly as they are the party to whom the responsibility and liability will be attributed.

\section{Conclusion}

This study examines the effect of exposure to litigation risk on the perception of auditors about their roles and responsibilities. The results have proved that auditors occupying lower-level jobs or positions in their respective audit firms assume more responsibilities and accountability for auditors' work. Owners of the audit firms (equity partners) and auditors in higher positions i.e. partners and audit managers assume fewer responsibilities and liabilities to third parties. The test of experience effect showed no significant differences in the perceptions of auditors' groups categorized based on the years of experience. Hence, the variation in the perceptions of auditors' groups categorized based on the position and the level of responsibilities in the audit firms is attributed to the effect of exposure to litigation risk. It is evident that audit partners are conservative and more precautious in estimating their responsibilities. They understand that according to the legislation, they will be held accountable for any audit failure even though the majority of technical audit work is performed by lower-level auditors. The responses of senior auditors and junior auditors' groups showed that they attribute more responsibilities to auditors even higher than those responsibilities specified by the auditing standards. They opine that auditing standards should make auditors responsible for detecting and reporting fraud. Furthermore, they confirm that auditing standards should make auditors legally liable for any subsequent discovery of a misstatement in the financial statements whether caused by errors or fraud. The inferences from this study results indicate that the opinion of lower-level auditors might change considerably when they are promoted to higher positions and the consequences of any litigations will be charged to them personally.

A considerable number of studies have been conducted on the audit expectation gap and proved the prevalence of the gap worldwide. Audit expectation gap research investigates the gap between what auditors do or required to do by auditing standards and what public in general and financial statements users, in particular, expect them to do. Typically, the results of this type of research show that financial statements' users have high and, most of the time, unreasonable expectations. However, this study provides evidence that another gap exists between auditors. Since all auditors, who have different perceptions, are providing the same auditing services, this gap cannot be identified as an expectation gap. This gap could be identified as the litigation threat gap. The gap is evident between auditors with lower litigation threats who propose more responsibilities and auditors with higher litigation threats (i.e. partners) who propose fewer responsibilities and liabilities to third parties.

\section{References}

(ACFE), A. o. C. F. E. (2018). Report to The Nation's 2018 Global Study on Occupational Fraud and Abuse. Retrieved from https:/www.acfe.com/uploadedFiles/ACFE_Website/Content/rttn/2018/RTTN-Asia-Pacific-Edition.pdf

Al-Dhubaibi, A. A. S. (2020). Auditors' responsibility for fraud detection: Views of auditors, preparers, and users of financial statements in Saudi Arabia. Accounting, 6(3), 279-290.

Alleyne, P., \& Howard, M. (2005). An exploratory study of auditors' responsibility for fraud detection in Barbados. Managerial Auditing Journal, 20(3), 284-303.

Best, P. J., Buckby, S., \& Tan, C. (2001). Evidence of the audit expectation gap in Singapore. Managerial Auditing Journal, $16(3), 134-144$.

Bierstaker, J. L., Brody, R. G., \& Pacini, C. (2006). Accountants' perceptions regarding fraud detection and prevention methods. Managerial Auditing Journal, 21(5), 520-535.

Bik, O., \& Hooghiemstra, R. (2018). Cultural Differences in Auditors' Compliance with Audit Firm Policy on Fraud Risk Assessment Procedures. Auditing: A Journal of Practice \& Theory, 37(4), 25-48.

Board, P. C. A. O. (2009). Concept Release on Requiring the Engagement Partner to Sign the Audit Report. PCAOB Release No. 2009-005.

Board, P. C. A. O. (2011). Improving the Transparency of Audits: Proposed Amendments to PCAOB Auditing Standards and Form 2. Concept Release No, 2011-2007.

Cole, C. J. (2014). Audit partner accountability and audit transparency: Partner signature or disclosure requirement. Journal of Accounting and Finance, 14(2), 84.

DeZoort, F. T., \& Harrison, P. D. (2018). Understanding auditors' sense of responsibility for detecting fraud within organizations. Journal of Business Ethics, 149(4), 857-874.

Fulop, M. T., Tiron-Tudor, A., \& Cordos, G. S. (2019). Audit education role in decreasing the expectation gap. Journal of Education for Business, 94(5), 306-313.

Gonthier-Besacier, N., Hottegindre, G., \& Fine-Falcy, S. (2016). Audit Quality Perception: Beyond the 'Role-Perception Gap'. International Journal of Auditing, 20(2), 186-201.

Hogan, C. E., \& Martin, R. D. (2009). Risk shifts in the market for audits: An examination of changes in risk for "second tier" audit firms. Auditing: A Journal of Practice \& Theory, 28(2), 93-118.

Honigsberg, C. (2019). The Case for Individual Audit Partner Accountability. Vanderbilt Law Review, 72(26). 
Huang, S. Y., Lin, C.-C., Chiu, A.-A., \& Yen, D. C. (2017). Fraud detection using fraud triangle risk factors. Information Systems Frontiers, 19(6), 1343-1356.

Kang, M., Lee, H. Y., Mande, V., \& Woo, Y. S. (2019). Audit Firm Attributes and Auditor Litigation Risk. Abacus, 55(4), 639675.

Kassem, R. (2018). Exploring external auditors' perceptions of the motivations behind management fraud in Egypt-a mixed methods approach. Managerial Auditing Journal, 33(1), 16-34.

Lee, T., Ali, A. M., \& Bien, D. (2009). Towards an Understanding of the Audit Expectation Gap. ICFAI Journal of Audit Practice, 6(1).

Lennox, C., \& Li, B. (2012). The consequences of protecting audit partners' personal assets from the threat of liability. Journal of Accounting and Economics, 54(2-3), 154-173.

Lin, Z. J., \& Chen, F. (2004). An empirical study of audit 'expectation gap'in the People's Republic of China. International Journal of Auditing, 8(2), 93-115.

Louwers, T. J., Henry, E., Reed, B. J., \& Gordon, E. A. (2008). Deficiencies in auditing related-party transactions: Insights from AAERs. Current Issues in Auditing, 2(2), A10-A16.

McKee, T. A. (2010). The'cry wolf'problem in current fraud auditing standards. The CPA Journal, 80(1), 60.

Noghondari, A. T., \& Foong, S.-Y. (2013). Antecedents and consequences of audit expectation gap: Evidence from the banking sector in Malaysia. Managerial Auditing Journal, 28(5), 384-406.

Payne, E. A., \& Ramsay, R. J. (2005). Fraud risk assessments and auditors' professional skepticism. Managerial Auditing Journal.

Peterson, B. K., \& Buckhoff, T. A. (2004). Anti-fraud education in academia. In Advances in Accounting Education Teaching and Curriculum Innovations (pp. 45-67): Emerald Group Publishing Limited.

Reddy, K., Venter, H., \& Olivier, M. S. (2012). Using time-driven activity-based costing to manage digital forensic readiness in large organisations. Information Systems Frontiers, 14(5), 1061-1077.

Rezaee, Z., Larry Crumbley, D., \& Elmore, R. C. (2004). Forensic accounting education. In Advances in accounting education teaching and curriculum innovations (pp. 193-231): Emerald Group Publishing Limited.

Robert Knechel, W., Vanstraelen, A., \& Zerni, M. (2015). Does the identity of engagement partners matter? An analysis of audit partner reporting decisions. Contemporary Accounting Research, 32(4), 1443-1478.

Ruhnke, K., \& Schmidt, M. (2014). The audit expectation gap: existence, causes, and the impact of changes. Accounting and Business Research, 44(5), 572-601.

Smith, M., Omar, N., Iskandar, S., \& Baharuddin, I. (2005). Auditors' perception of fraud risk indicators: Malaysian evidence. Managerial Auditing Journal, 20(1), 73-85.

Tang, J., \& Karim, K. E. (2019). Financial fraud detection and big data analytics-implications on auditors' use of fraud brainstorming session. Managerial Auditing Journal, 34(3), 324-337.

Venkataraman, R., Weber, J. P., \& Willenborg, M. (2008). Litigation risk, audit quality, and audit fees: Evidence from initial public offerings. The Accounting Review, 83(5), 1315-1345.

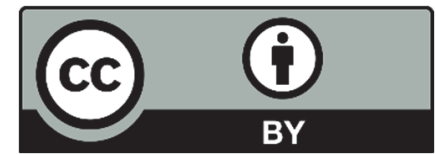

(C) 2021 by the authors; licensee Growing Science, Canada. This is an open access article distributed under the terms and conditions of the Creative Commons Attribution (CC-BY) license (http://creativecommons.org/licenses/by/4.0/). 